\title{
Challenges in Teaching English for EFL Learners at Pesantren: Teachers' Voices
}

\author{
Lenny Marzulina \\ Universitas Islam Negeri Raden Fatah Palembang, Palembang, Indonesia \\ Kasinyo Harto \\ Universitas Islam Negeri Raden Fatah Palembang, Palembang, Indonesia \\ Dian Erlina \\ Universitas Islam Negeri Raden Fatah Palembang, Palembang, Indonesia
}

Muhammad Holandyah

Universitas Islam Negeri Raden Fatah Palembang, Palembang, Indonesia

Deta Desvitasari

Universitas Islam Negeri Raden Fatah Palembang, Palembang, Indonesia

Arnilawati Arnilawati

Universitas Islam Negeri Raden Fatah Palembang, Palembang, Indonesia

Fridiyanto Fridiyanto

UIN Sulthan Thaha Saifuddin Jambi, Indonesia

Amirul Mukminin

Universitas Jambi, Jambi, Indonesia

\begin{abstract}
The aim of this study was to find out the challenges faced by teachers of English in teaching English at pesantren (Islamic boarding schools). This study was qualitative research with a case study approach. The participants of this study were two teachers of English at pesantren in MUBA regency. To find out the challenges faced by the teachers in teaching English, the data gained from observation and interviews were analyzed by using thematic analysis. The findings indicated that there were five challenges faced by the teachers of English in teaching English: 1) improving students' motivation; 2) improving students' language competence; 3) managing over-crowded class; 4) managing limited time; and 5) facing lack of supporting facilities. Implications of the findings are also discussed.
\end{abstract}

Index Terms - challenges in teaching English at pesantren, Islamic boarding school, teaching English

\section{INTRODUCTION}

Islamic boarding school, known as pesantren is one of the Islamic institutions that are well-known for its education quality and its superiority in teaching language to its students. As the oldest Indonesian education schools, pesantrens have historically implemented English as a foreign language (EFL) as one of the compulsory subjects in their curriculum (Daulay as cited in Habibi et al., 2018, p. 2105). In addition, the 2003 Law on the Indonesian educational system gives English a place as the first foreign language among other foreign languages used in Indonesia such as German, Arabic, or Japanese (Komaria, 1998 as cited in Abrar et al., 2018, p. 129). It means that, pesantren also give foreign subject to be learned by students, the foreign subjects are Arabic and English. As a foreign language, teaching English has challenges, such as a lack of proficiency in speaking skills. Speaking is one of the most challenging skills. There has been a lack of literature and information on EFL student teachers' experiences in speaking English in the context of Indonesia (Mukminin et al., 2015). Besides, limited time is also a problem in learning English (Gultom, 2015). Generally, the time to study English is not enough for the students to learn and use the language. Similarly, in the 2013 curriculum, time allocation for English subject at schools is reduced. This condition can lead to some consequences for the quality of EFL in Indonesia (Sahiruddin as cited in Pitaloka, 2014, p. 2).

Teaching English in Indonesia is not always running well. Challenges in teaching English are also frequently faced by English teachers in Indonesia. Related to challenges in teaching English, Songbatumis (2017) found that some challenges emerged, from students, teachers, and the school's facility. Students are challenged by their lack of 
vocabulary mastery, low concentration, lack of discipline, boredom, and speaking problems. Meanwhile, teachers' challenges are short-age of training, language proficiency issues, limited mastery of teaching methods, unfamiliarity with technology, and lack of professional development facilities, resources, and time constraints.

Based on the explanation above, there was a need to conduct a study to investigate deeper about challenges faced by teachers at one Indonesian pesantren. Results of the study can be useful information for English teachers, schools, government to create better policies that can improve English Language Teaching (ELT) in pesantren. The main purpose of this study was to investigate the challenges faced by teachers in teaching English at pesantren.

\section{LITERATURE REVIEW}

There are three main challenges for the teachers in teaching English as a foreign language. Copland, Garton and Burns (2014) mentioned that there are three challenges commonly faced by English teachers in teaching English, as follows; a) teachers' proficiency; b) classroom management c) government policy and curricula. Those challenges will be described below. The first challenge is the teacher's proficiency. A good proficiency level is needed for a teacher, especially for English teachers. Unfortunately, many teachers have low proficiency levels, and lack confidence. Second, many English teachers have difficulty in teaching English, especially in large classes where a classroom consists of more than 30 students. Teachers cannot closely monitor students' language use, and the problem of discipline. Third, teachers must teach English based on the curriculum and policies set by the government. The curriculum used is incompatible.

Furthermore, Khaljoo (2013) argued that there are several challenges in teaching and learning English. The first is low hours of English language teaching. Some experts complain about the amount of time devoted to the course and believe that in many cases teachers cannot teach all subjects in this limited time. Second, lack of interest and motivation for learning English. Most students are not interested in learning the language and just think about passing the course. Thus because they are not interested, they do not listen to their teacher. They do not learn anything. Even if they learn something, they will forget it quickly because they are tired of its repetition. Third, the next factor is the lack of concentration. When students do not have concentration cannot learn the material. The fourth is students who are ahead of others. Another difficulty in English teaching relates to those students who attend English classes outside of school. Next, most English teachers lack proficiency in the English language. Unfortunately, most high school teachers are not fluent in English and cannot teach the English language orally. The last is lack of repetition and frequent practice of students. Since students are not interested in learning English, so they will be tired of repeating and practicing the language.

In addition, teaching English is not always running well. The teachers of English have some major challenges in teaching English in classroom. According to Lynch (2008, as cited in Fajaryani, Masbirorotni, Nuraini, Nafrial, and Nopianti, 2018, p. 67), there are three most crucial challenges in teaching and learning English in classroom, as follows; First, lack of motivation, learners may not have inspired and interested towards the learning of English language. They fear failure in exams and even in classroom interaction, so they cannot get involved easily in classroom interaction and learn the language comfortably. They must be motivated by teachers to learn English in classroom interaction. Second, insufficient time allocation, resources, and materials, English is a foreign language, and hence it cannot be learned and taught as easily as a mother tongue or first language. And when it is learned or taught as a second language, it requires a long time and simultaneously adequate resources and materials to create an English classroom climate that facilitates teaching-learning process. Third, over-crowded classes, the number of students in a classroom can range from one, for those who teach individual private students, to fifteen or twenty students in a typical classroom up to multitudes of thirty-five or forty or even fifty or more students packed into a language leaning situation. The large classes create several problems such as discomfort, less attention, evaluation, difficulty in managing class, maintaining learning effectiveness, etc. Those three main challenges, as mentioned above, are necessarily needed to be overcome to improve the quality of English Language Teaching.

\section{Methodology}

\section{A. Research Design}

A case study design was applied as the research design in this study. Creswell (2014) says a case study is a qualitative approach that involves the study about an issue explored through one or more cases over time through detailed, in-depth data collection involving multiple sources of information (Mukminin et al., 2017). This study investigated the causes of challenges in teaching English for EFL learners at one pesantren located in MUBA regency using observation and interviews to gather the data. The participants of this study were two English teachers that have much information related this research.

\section{B. Data Collection and Analysis}

The data from observation was needed to answer the research objective, which was about the challenges faced by English teachers in teaching English at pesantren in MUBA regency. The observation checklist consisted of some indicators, mastery of the material, classroom management, facilities, and student's motivation. The observation 
checklist was useful to observe the challenges faced by teachers of English within teaching English in class. The data were also collected through interviewing teachers of English at pesantren in MUBA regency. In interviewing the participants, we used a semi-structured interview to answer general and specific questions. General questions were used to answer about general challenges and practice of English language teaching. On the other hand, specific questions were used to answer some questions, which consisted of some indicators, teachers' proficiency, and mastery of material, classroom management, class size, facilities, student assessment, students' motivation, government policy, and curricula.

In analyzing the data, we used thematic analysis to analyze the observation and interview data to answer the research problem. Braun and Clark (2006) stated that thematic analysis identifies, analyzes, and reports themes within data. Braun and Clark (2006) mentioned that there are six steps commonly used in analyzing qualitative data, as follows; (1) the researcher have to be familiar with the entire body of data (2) generate codes, (3) search for themes (4) review themes (5) define and name themes, and (6) produce the report.

\section{Trustworthiness}

We validated the data triangulation was used to check the validity the data. According to Creswell (2012), triangulation is the process of corroborating evidence from different individuals (example, between principal and student), types of data collection (e.g., observational fields notes and interviews), or methods of data collection (e.g., between document and interviews) in descriptions and themes in qualitative research. We used methodological triangulation technique in this study. Methodological triangulation is a technique that uses a different method on the same object study. Then, the data from observation and interview had to be cross-checked. Finally, those data combined with corroborating each other.

\section{FINDINGS}

The research findings presented the challenges in teaching English faced by the teachers of English at one pesantren in MUBA regency. The data of this research were obtained from observation checklist and interviews of the teachers of English. An in-depth interview was done using both Indonesia and Sekayu languages (local language) because the local language was easier to understand. Besides, we hid the participants' names; the first participant (P1), the second participant (P2). All the data were collected from observation and interviews with the participants involved in this study. After analyzing the data from observation and interviews, we found some challenges faced by the teachers of English in teaching English. The themes and codes gained from thematic analysis were described in Table 1. 
TABLE 1

Themes ANd Codes Teachers' ChaLLENGes In TEACHING ENGLish

\begin{tabular}{|c|c|c|c|}
\hline No & Themes & Code & \\
\hline 1. & $\begin{array}{l}\text { Teachers were challenged to improve } \\
\text { students' motivation }\end{array}$ & B. & $\begin{array}{l}\text { In speaking activities, most students looked less active and not } \\
\text { confident to speak English. Teachers were challenged to encourage the } \\
\text { students to be more active, confident and engaged in using spoken } \\
\text { English. } \\
\text { In listening activities, some students looked less interested in learning } \\
\text { because there was no language laboratory and the audio device } \\
\text { provided was so poor that teachers were challenged to make the } \\
\text { students more interested in listening activities. } \\
\text { In reading activities, most of the students looked shy and afraid of } \\
\text { making pronunciation mistakes in reading text. Teachers were } \\
\text { challenged to give motivation to make the students more confident and } \\
\text { enthusiastic. }\end{array}$ \\
\hline 2. & $\begin{array}{l}\text { Teachers were challenged to improve } \\
\text { language competence of the students }\end{array}$ & B. & $\begin{array}{l}\text { In speaking ability, most students lacked vocabulary and } \\
\text { pronunciation, so teachers were challenged to improve students' } \\
\text { speaking skills by enhancing student's vocabulary mastery. } \\
\text { In writing ability, most students lacked of ideas and had grammatical } \\
\text { errors in writing essays, so that teachers were challenged to develop } \\
\text { students' ideas and improve students' grammar. } \\
\text { In reading ability, most students had difficulty understanding the } \\
\text { content of reading text, so that teachers were challenged to enhance } \\
\text { students' comprehension. } \\
\text { In listening ability, most students who sat in the back lacked } \\
\text { understanding of the audio recording. The teacher was challenged to } \\
\text { prepare the listening comprehension easier to understand by the } \\
\text { students. }\end{array}$ \\
\hline 3. & $\begin{array}{l}\text { Teachers were challenged to manage over- } \\
\text { crowded class }\end{array}$ & $\begin{array}{l}\text { C. } \\
\text { D. }\end{array}$ & $\begin{array}{l}\text { In speaking activities, some students lacked attention to the teacher } \\
\text { because the students were disturbed by other friends so that teachers } \\
\text { were challenged to make the students pay attention. } \\
\text { In reading activities, some students did not get opportunity to read text, } \\
\text { so that teachers were challenged to manage students' opportunity to } \\
\text { read. } \\
\text { In listening activities, most students sitting in the back always asked } \\
\text { for recording repetition though they were given limited repetition. } \\
\text { In writing activities, most of the students were noisy, and the students } \\
\text { cheated with their friends in doing the task, so the teachers were } \\
\text { challenged to be more aware and assertive to the students. }\end{array}$ \\
\hline 4. & $\begin{array}{l}\text { Teachers were challenged to manage time } \\
\text { allocation }\end{array}$ & $\begin{array}{l}\text { A. } \\
\text { B. }\end{array}$ & $\begin{array}{l}\text { In speaking session, the teachers were challenged to manage students' } \\
\text { talking time in speaking by the allocated time. } \\
\text { In writing session, most of the students could not finish writing the } \\
\text { essay. They were only able to finish } 1-2 \text { paragraphs out of } 3 \\
\text { paragraphs so that the teachers were challenged to manage time and } \\
\text { give the lesson in accordance with students' writing ability. } \\
\text { In reading session, most of the students could not finish task on time } \\
\text { because they need more time to understand text. Teachers were } \\
\text { challenged to manage time by giving the material following students' } \\
\text { reading ability. } \\
\text { In listening session, time to practice was less because the duration of } \\
\text { the audio recording too many repetitions. The teachers had to manage } \\
\text { time in each session in the listening activity. }\end{array}$ \\
\hline 5. & $\begin{array}{l}\text { Teachers were challenged to face lack of } \\
\text { supporting facilities }\end{array}$ & & $\begin{array}{l}\text { In speaking activities, teachers were challenged to use various media } \\
\text { provided by the school, such as handouts, pictures, videos, and others. } \\
\text { For listening activities, this school did not provide supporting facilities } \\
\text { to teach listening, such as laboratory and speaker. Teachers were } \\
\text { challenged to bring and use their own speaker in teaching listening. } \\
\text { In reading activities, this school only provided teachers' handbooks. It } \\
\text { did not provide students' handbooks so that teachers were challenged } \\
\text { to use other media such as handouts, novels, fairy tale books, fable } \\
\text { books, etc. }\end{array}$ \\
\hline
\end{tabular}

\section{A. Improving Students' Motivation}

Based on the data collected from the observation and interview, we found that one of the challenges faced by the teachers of English in teaching was the students' lack of motivation in learning English. In this case, students who had low motivation did not focus and were not active in learning English. Based on the data gained from the interviews, we found a challenge confronted by the teacher when the students had less concentration or less focus in learning English. Consequently, the students having low motivation could be a problem in learning English. For example, participant 1 (P1) said that, "Yes of course, it was a challenge for me in teaching English, when the student lack of motivation in learning the student will lose their concentration or do not focus in the lesson" (personal communication, April 20, 2019). Besides, the participant 2 (P2) argues, "Yes of course. It was a challenge for me. For example, the student leaves the class when study, talking with their friend at study, and then, if I asked them, they do not know, and so on" (personal 
communication, April 19, 2019). Subsequently, challenges in terms of students' motivation could be seen from learning activities, especially in teaching speaking, reading, and listening. The result of observation would be an explanation of those challenges. The result of observation in speaking activities showed that the students seemed lazy and less active in speaking English. In speaking activity, when the students were asked to speak in front of the class the students were not ready to speak, and most of the students looked scared and nervous in speaking. In addition, other students who were sitting talked to his friend about topics that had no relation to the current topics discussed, and most of the students did not pay attention to his friend presented in front of the class. Therefore, the teachers were challenged to stimulate the students to be more active and involved in learning English.

In reading activities, most of the students looked shy and hesitant in reading textbook. Based on observation data, when the teacher asked the students to give their opinions, read text, and answer teacher's questions, most of students were shy and confused. Furthermore, some of students sitting in the back row went to sleep, not being active and less giving attention when the teacher was explaining. In teaching reading, the teachers were challenged to improve students' motivation to learn English to become more passionate and confident in learning English.

In listening activities, the result of observation showed that some students showed less interest in learning listening because there were no language laboratory and audio devices provided. Moreover, the students did not learn listening and the teacher skipped this activity because there were no facilities provided to support teaching listening activities. The teacher was challenged to improve students' motivation in listening activity by providing interesting lessons in teaching listening.

\section{B. Improving Language Competence of Students}

The data gained from the interview showed that the teacher's challenge in teaching English is when the students had less language competence. The students having less competence could be found in some activities, such as speaking activity, reading activity, and writing activity, which become challenges for teachers in teaching. The teachers were challenged to improve the language competence of students. For example, Participant 2 (P2) said that, "the students' ability in English here was poor, it is because they were not interested in learning English so English competence here is still poor" (personal communication, April 19, 2019). Participant 1 (P1) shared the same opinion. The challenges of language competence were explained below. Subsequently, the result of observation and interview showed that teachers were challenged to improve students' speaking ability. In observation, we found most of the students had a lack of vocabulary and mispronounced the English words. In the speaking activity, we found that most students had difficulty pronouncing the English words when they were asked to speak English. This issue commonly appeared when the teacher of English was teaching speaking. For example, participant 1 (P1) said that, "lack of students mastery in English pronunciation" (personal communication, April 20, 2019).

In addition, the teachers of English were challenged in presenting the material because the students had limited vocabulary. In speaking activities, most of the students did not understand the meaning of the words contained in the material. The students who had limited vocabulary could be a challenge for the teacher in teaching. For example, participant 1 (P1) argues that "Lack of vocabulary mastery is a problem in teaching. If I asked to speak English they were confused even did not answer what I ask caused they did know the meaning and lack of vocabulary mastery" (personal communication, April 20, 2019). Another challenge related to language competence has to improve writing skills. In observation, most students seemed to lack ideas and had difficulties in organizing paragraphs grammatically. The students' lack of grammar caused them to have limited vocabulary and could not make the sentences correctly. Therefore, the teachers were challenged to make students write sentences correctly and develop students' ideas in writing. The next challenge related to students' language competence was that students had difficulty understanding the text of reading comprehension. Based on the observation in the reading activity, most students did not understand the text they read. Additionally, when the students were asked to answer the reading comprehension questions, they did not know how to answer the questions since they did not understand the meaning of the questions and the text. The teachers were challenged to enrich the students about the reading text so that the students could understand the reading text and answer the reading comprehension questions.

The last challenge related to students' language competence was that students lack understanding of the audio recording. Based on the observation in the listening activity, most students who sat in the back had difficulty listening to the audio recording well. They always asked to record repetition because the students could not answer the listening comprehension. The teacher was challenged to enrich the students about listening comprehension and prepared the easy material.

\section{Managing Over-Crowded Class}

Based on the data gained from observation and interviews, we found that challenge faced by teachers of English in teaching English was managing the over-crowded class. The problem in managing an over-crowded class commonly occurred in teaching English in a large class. For example, participant 1 (P1) said that, "one of the challenges for me in teaching was managing the class which had many students and the number of students more than 30 students like VII grade male that I taught the number of student consists of 37 students" (personal communication, April, 20, 2019). Therefore, participant $2(\mathrm{P} 2)$ also gives opinions, "yes of course, the number of students becomes challenges for me if the number of students a lot" (personal communication, April 19, 2019). In addition, the challenges in managing an 
over-crowded class would be seen from observation in learning activities, especially in teaching speaking, reading, and listening. The explanation would be described below.

The observation in speaking activity showed that if the number of students was more than 30, most of the students rarely paid attention. In speaking activity, when the teacher spoke in front of the class, most students did not pay attention and talked out the topic with their friends. The teacher could not monitor students one by one because there were many students in the class. In teaching speaking, teachers were challenged to make students pay attention. In reading activities, some students did not get the opportunity to read text. Based on observation, teaching English in a large class was a challenge for teachers because they had to manage time effectively in teaching reading, so the students could read text one by one. In teaching reading in a large class, the teachers were challenged to manage everything effectively. In listening activities, teaching English in a large class, especially teaching listening, teachers had challenges if there were many students in the class, the learning was not conducive. Based on the result of observation, students were always asking for repetition though they were given the limited time of repetition. During the lesson, the students were only given three times to listen to the audio recording on tape, but most of the students did not understand the story they listened from the recording. Consequently, teachers were asked by the students to repeat the recording. In writing activities, teaching English in a large class, especially writing, teacher had challenges being awarded and assertive to the students. Based on the observation, most students were noisy during writing activities, and the students did cheat in doing the task.

\section{Managing Limited Time}

Based on the observation and interview data, we found that challenge faced by teachers in teaching was time allocation. In this pesantren, English subject was taught only two meetings in a week. The time used to learn English was only 90 minutes in a meeting. Therefore, English is taught for a limited time. Consequently, English teachers were challenged to give the lesson effectively and efficiently in a limited time. The data from the interview showed that time allocation provided by the school was limited. Thus, the teacher had to manage the time effectively and efficiently. For example, participant 1 (P1) said, "I think, time to learn English in this pesantren is not enough because English is a foreign language, not our language, so that we need more time to learn it. I always need more time to explain the material, and also, the students cannot learn English well if time was limited. Here, we learn English may $3 / 4$ hours in a week because English is primitive than Arabic" (personal communication, April 20, 2019). Therefore, participant 2 (P2) also said, "I think the time to learn English here is very inappropriate because I need more time in teaching. Here, only two meetings in a week and time to learn are only 40 till 60 minutes in a meeting" (personal communication, April 19, 2019). English teachers were challenged to manage time, especially in teaching speaking, reading, and writing. The challenge of managing time in teaching speaking, reading, and writing would be described below.

In speaking activities, the teachers were challenged to manage their talking time and students' talking time in accordance with the allocated time. In teaching speaking, teachers should give the lesson effectively and efficiently. The observation in speaking class showed that some of the students had no chance to speak because the time provided was over. Consequently, some students could not speak in front of the class and it would be continued in the next meeting. To sum up, the teachers had the challenge to teach speaking in accordance with the allotted time. In writing activities, the teachers' challenges in teaching writing were that the teachers had difficulty managing time in giving writing tasks to the students. The result of observation showed that when the writing activity was almost over, most students were only able to do some paragraphs from 3 paragraphs. In observation, most students seemed confused in writing essay, and then some of the students were cheating with their friends. It may be caused by the students' ability which was still poor in doing writing essay in limited. In writing the essay, it would take a longer time to be done. It had become a crucial challenge for teachers. Teachers were challenged to manage time and to give the lesson in accordance with students' writing ability.

The next challenge of managing limited time occurred in the reading activity. The material used to learn reading was very difficult. In observation, the students were asked by the teacher to drill some questions in the handbook. Most of students seemed confused and most of the students had difficulty in doing reading comprehension that the teacher gave. In reading activity, the teacher was challenged to manage time allocated in accordance with material and students' reading ability. The last challenge of managing limited time encountered in listening activities. Time to practice listening comprehension was less. In my observation result, the students sat in the back asked recording repetition whereas time was limited so that most of the students did not finish their work. The teacher was challenged to manage part of each session well in listening comprehension.

\section{E. Facing Lack of Supporting Facilities}

Based on the data gained from observation and interview, we found that facilities in this Pesantren became issues and challenges for the teacher of English in teaching. Most of the facilities that support the teaching learning process were unavailable such as, students' and teachers' books, language laboratory, projector, audio devices and others that can be used to learn. The data from interviews showed that the teachers had difficulties using facilities in teaching. For example, participant 1 (P1) said that, "Facilities in this pesantren was very limited, so it is become the challenges for me as a teacher, almost in every class there is no enough facilities like media electronic or other media" (personal 
communication, April, 20, 2019). After that, participant 2 (P2) says "I think the facilities in this pesantren has not fulfilled" (personal communication, April 19, 2019).

In line with the interview data, the teachers faced challenges related to teaching listening. In teaching listening, there were no facilities provided by the school to support teaching English. In fact, there was no laboratory to teach listening and there was no audio device to be used. In observation, when the teacher was teaching listening, the students were not interested in learning because the listening process was taught by using poor audio devices. For facing insufficient facilities in teaching listening, the teachers were challenged to use poor speakers provided or bring and use their speakers to teach listening.

In teaching speaking, the school did not provide various media as learning sources. The school only provided teacher's and students' handbooks as learning sources. In observation of speaking class, the teacher taught speaking by asking the students to make a dialogue presented in front of the class. In brief, the teachers were challenged to use various media that were not provided by this school, such as handouts, pictures, videos, and others.

The last challenge related to insufficient facilities occurred in teaching reading. In teaching reading, the teachers only depended on the book. Meanwhile, the book contained difficult material. This made the students difficult to understand the text. The result of observation showed that teacher only used the handbook in teaching reading without using additional media because the facilities provided by the school were inadequate. It had become a challenge for the teachers to use insufficient facilities provided by this school or bring and use additional media that the school did not provide.

\section{DISCUSSION}

After we analyzed the data using thematic analysis, we found that teachers of English faced several challenges. One of the challenges was the students' lack of motivation. Dörnyei (2012) says that motivation determines human behavior and gives direction to achieve it. He lists motivational components that are categorized into three main dimensions. In another explanation, Küpers (2011) states that demotivation is a reduced driving force for thinking, feeling, and acting that causes someone is not active. Students who had low motivation were considered a challenge the teachers of English should consider to enhance students' motivation. The teachers were challenged to encourage the students to be more active and engaged in learning speaking, reading, and listening.

Further, we also found that challenges in teaching English faced by teachers were when their students had a lack of language competence. Therefore, when the teacher explained material but the students lacked mastering vocabulary, the teacher had to explain the meaning of vocabulary used by the teacher. This result was in line with Songbatumis (2017), who found that challenges in teaching English in the classroom are students' lack of vocabulary mastery. It hindered the students' understanding of the subject. Some students might have a lack of vocabulary mastery which makes them not actively participate in class.

In line with it, the challenge faced by teachers of English was students' lack of pronunciation mastery. In speaking, some of the students could not pronounce words in English correctly. The result was similar to the researcher conducted by Songbatumis (2017) who found that most of students commit errors in pronouncing words. In writing activity, most students lacked ideas and had difficulty organizing paragraphs grammatically in writing essays. Fatiloro (2015) says that dictionaries, grammar guides, and the web should always be the tool for consultation when teaching and learning English.

Furthermore, an over-crowded classroom was also a challenge in teaching English faced by the teacher. It made the teaching and learning process not effective. The result is similar to the research conducted by Gultom (2015) who found that the problems of English language teaching in Indonesia were the class size. No matter what teaching method is used, the result of the English teaching and learning will not be satisfactory. Then, Al-amarat (2011) found that "overcrowded classrooms with students". "It may refer to classroom overcrowding, which may prevent the implementation of classroom management strategies". Subsequently, lack of time allocation was also a challenge in teaching English faced by the teacher. Lynch (2008) mentioned that insufficient time allocation, resources, and materials are the problems in teaching and learning English as a foreign language which it requires long time. English teachers had to teach English in limited time and lack of repetition which they had been teaching a meeting in a week. The challenge faced by the teacher when she taught English in limited time was the teacher had difficulty in managing the time for transferring information, because time available for teaching English was only 90 minutes in one meeting. This challenge is similar to the research conducted by Habibi, Mukminin, Najwan, Haswindy, Marzulina, Sirozi, Harto, \& Sofwan, (2018) in which time is the factor that we should pay attention. We have difficulties to manage the time in every meeting. Students are hard to understand the materials in a limited time while English is tested in the national exam. We sometimes skip some unimportant activities. In addition, Songbatumis (2017) also found that the time provided was not enough to apply teaching ideas in the classroom and improve their professional development. Time provided to teach English was only two hours for each meeting, to be exact, 90 minutes in every meeting, whereas, these participants expect that the ideal time to teach English is 90 minutes for each meeting.

Another challenge faced by teachers in teaching English was the lack of facilities. Ajibola (2010) said that, "ensuring the availability of sufficient textbooks, computers, listening devices, hands on tools, and other teaching instruments is a challenging assignment". In this research, we found that the resources and facilities were insufficient. It made the 
teachers of English facing the challenge in teaching. They did not use electronic media to support the teaching learning process. Therefore, the resources like text books were limited to be used, and even MTs level did not use text books when learning English. This result was congruent with Teevno's (2011) study, who found that "Though the majority of the schools have their libraries, none of these have the provision of English newspapers, no computers, and audio visual aids".

From the results above, we concluded that being a teacher was not easy because there are many challenges found in teaching. Many challenges are faced by teachers both the challenge from the students, and school as well. Besides, we also realized that the government's role is important to improve teaching learning at school, such as giving the facilities to support the teaching learning process.

\section{CONCLUSIONS}

Using a case study approach, the findings of this study contribute to our understanding of the challenges faced by teachers of English in teaching English at pesantren (Islamic boarding schools). Overall, the findings of this study exposed that there were some challenging factors in teaching English faced by the teachers of English such as a) improving students' motivation, b) improving language students' competence, c) managing over-crowded class, d) managing limited time, and e) facing lack of supporting facilities. This research only focused on finding out the challenges in teaching English. The next researchers may conduct similar research to find the challenges in teaching English which are not explained in this study. Subsequently, based on what we found in this study, we expected that the teachers may reduce the challenges by doing several activities such as giving a warming up for students or introducing new vocabulary for them, reminding students to bring a dictionary and motivating them. Last, for the facilities issues, school should provide facilities that support the teaching and learning processes such as a language laboratory, teachers and students' handbooks, and time allocation to learn. Government could provide more materials and add the time in meeting to learn English to reduce challenges faced by teachers in teaching English.

\section{REFERENCES}

[1] Abrar, M., Mukminin, A., Habibi, A., Asyrafi, F., Makmur, M., \& Marzulina, L. (2018). If our English isn't a language, what is it? Indonesian EFL student teachers' challenges speaking English. The Qualitative Report, 23(1), 129-145.

[2] Ajibola, M. A. (2010). Confronting the challenges of teaching English language as a second language in Nigeria. Journal of the Nigeria English Studies Association (JNESA, ) 13(2), 95-105.

[3] Al-amarat, M.S. (2011). The classroom problem faced by teachers at the public school in Tafila province, and proposed solution. International Journal of Education Science, 3(1), 3-48.

[4] Braun, V., \& Clark, V. (2006). Using thematic analysis in psychology. Qualitative Research in Psychology, 3(2), 77-101.

[5] Copland, F., Burns, A., \& Garton, S. (2014). Challenges in teaching English to young learners: Global perspectives and local realities. TESOL Quarterly, 48(4), 740-741.

[6] Creswell, J., W. (2012). Educational Research: Planning, conducting, and evaluating quantitative and qualitative Research (4 ed). Boston, MA: Pearson Education, Inc.

[7] Creswell, J. W. (2014). Research Design: Qualitative, Quantitative, and Mixed Methods Approaches. Thousand Oaks, CA: Sage Publications.

[8] Dörnyei, Z. (2012). Motivation in second and language learning. Language teaching. London: Thames Valley University.

[9] Fajaryani, N., Masbirorotni, Nuraini, Nafrail, \& Nopianti. (2018). Different madrasah, but the same stories: Academic and non-academic challenges encountered by teachers in teaching a foreign language. Ta'dib Jurnal of Islamic Education, 23(1), 66-84.

[10] Fatiloro, O. F. (2015). Tackling the challenges of teaching English as second language (ESL) in Nigeria. Journal of Research \& Method in Education, 5(2), 26-30.

[11] Gultom, E. (2015). English language teaching problems in Indonesia. International Seminar on Regional Education, (3), 12341240.

[12] Habibi, A., Mukminin, A., Najwan., Sofwan, M., Marzulina, L., \& Harto, K. (2018). Investigation EFL classroom management in pesantren: A case study. The Qualitative Report, 23(9), 2105-2122.

[13] Khaljoo, A. (2013). Problems in teaching and learning English for students. International Journal of Engineering Research and Development, 7(3), 56-58.

[14] Küpers, W. (2001). A Phenomenology of embodied and the demotivational realities of the organisations. Retrieved from: http://www.mgnt.ac.nz/ejrot/cmsconference/2001/Papers/Passion\%20for\%20Organising/Kupers.pdf on January 5, 2021

[15] Lynch, L. M. (2008). Three critical problems in English language teaching and learning and what to do about them. Retrieved from http://ezinearticles.com/?Three-Critical-Problem-in-English-Language-Teaching-and-Learning-and-What-to-Do-AboutThem\&is=986839 on January 5, 2021

[16] Mukminin, A., Novprival, N., Masbirorotni., Sutarno., Arif, N., \& Maimunah. (2015). EFL Speaking Anxiety among Senior High School Students and Policy Recommendations. Journal of Education and Learning (Edularn), 9 (3), 217-225.

[17] Pitaloka, N. (2014). Developing interactive multimedia with local content based narrative texts for grade eight. Jurnal Bahasa \& Sastra, 15(1), 1-22.

[18] Sofwan, M, \& Habibi, A., (2016). English teaching implementation in Indonesia pesantren: Teacher' demotivation factors. IJET, 5(2), 200-212.

[19] Songbatumis, A. (2017). Challenges in teaching English faced by English teachers at MTsN Taliwang, Indonesia. Journal of Foreign Language Teaching and Learning, 2(2), 54-67. 
[20] Teevno, R, A., (2011). Challenges in teaching and learning of English at secondary level class X. International Journal of Human Resource Studies, 1(2), 27-35.

Lenny Marzulina is an associate professor, Universitas Islam Negeri Raden Fatah Palembang, Indonesia. Her research focuses on language teaching, TEFL, and English education and applied linguistics.

Kasinyo Harto is a full professor, Universitas Islam Negeri Raden Fatah, Palembang, Indonesia. His research interests are teaching and learning in higher education, multicultural education, educational management, and education in Muslim countries.

Dian Erlina is an associate professor, Universitas Islam Negeri Raden Fatah Palembang, Indonesia. Her research focuses on language teaching, TEFL, and English education and applied linguistics.

Muhamad Holandyah is an assistant professor, Universitas Islam Negeri Raden Fatah Palembang, Indonesia. His research focuses on language teaching, TEFL, and English education and applied linguistics

Deta Desvitasari is a lecturer at Universitas Islam Negeri Raden Fatah Palembang, Indonesia. Her research focuses on language teaching, TEFL, and English education and applied linguistics.

Arnilawati has a BA in English education from Universitas Islam Negeri Raden Fatah Palembang, Indonesia. Her research focuses on language teaching, TEFL, and English education and applied linguistics.

Fridiyanto is an assistant professor, UIN Sulthan Thaha Saifuddin Jambi, Indonesia. His research interests include education, language education, multicultural education, educational policy and management.

Amirul Mukminin is a full professor, Universitas Jambi, Faculty of Teacher Training and Education, Indonesia. His research interests include education, language education, international education, educational policy and language policy. 